\title{
Die effek van die ontvang van selfoonboodskappe op speekselkortisolvlakke in voorgraadse Fisiologiestudente
}

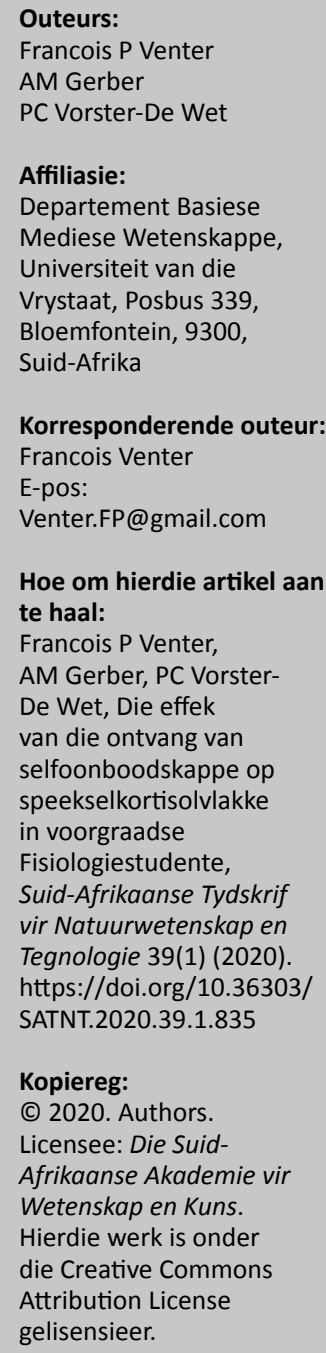

\begin{abstract}
The effect of receiving mobile text messages on salivary cortisol levels in undergraduate Physiology students: This research aimed to study the effect of receiving mobile text messages on salivary cortisol levels in Physiology students at the University of the Free State. Participants completed questionnaires and provided cortisol samples in the form of saliva during a Physiology lecture.
\end{abstract}

Navorsing toon dat bykans alle studente 'n selfoon besit. Uit selfone se talle funksies, het hierdie studie een van die oudste en eenvoudigste funksies ondersoek, naamlik teksboodskappe (texting), wat deur die meeste selfooneienaars gebruik word. Teksboodskappe is 'n kommunikasiemetode wat toelaat dat kort teksboodskappe tussen selfone gestuur en ontvang kan word. Suid-Afrika is die land met die meeste slimfoongebruikers in Afrika en die aktiwiteit waaraan die meeste tyd op 'n selfoon bestee word, is om teksboodskappe te stuur. Baie navorsers rapporteer oor die uitwerking wat teksboodskappe op aandag, akademiese prestasie, die onthou van akademiese werk en akademiese afleibaarheid het, om enkeles te noem. Alhoewel daar reeds bepaal is dat teksboodskappe verskeie fisiologiese stelsels negatief kan beïnvloed, kan teksboodskappe as hulpbron met groot sukses in studies oor gesondheidsingrypings en in ander navorsingsvelde gebruik word.

Die doel van hierdie navorsingstudie was om vas te stel watter effek die ontvang van selfoonboodskappe op speekselkortisolvlakke in Fisiologiestudente aan die Universiteit van die Vrystaat het. In totaal het 48 individue aan die studie deelgeneem deur vraelyste in te vul en speekselmonsters gedurende 'n lesing te voorsien. Deelnemers het as hulle eie kontroles gedien in 'n oorkruis-navorsingsontwerp. Op een dag het hulle die ingryping ondergaan (om boodskappe te ontvang) en op die alternatiewe dag het hulle nie die ingryping ontvang nie.

Vraelyste is gebruik om demografiese inligting in te samel. Angs, depressie, stres en deelnemers se subjektiewe ervaring van die ingryping is ook gemeet. Hierdie data is vergelyk met objektief-gemete speekselkortisolvlakke vir elke deelnemer deur'n laboratoriumontleding genaamd "enzyme-linked immunosorbent assay" (ELISA) te gebruik.

Ontleding van speekselkortisolvlakke wat stres aandui, het getoon dat kortisol 'n sirkadiese ritme van afskeiding het. Vlakke piek soggens en daal dan geleidelik deur die dag tot by 'n laagtepunt rondom middernag en bly relatief konstant van dag tot dag. In hierdie studie het speekselkortisolvlakke by meeste van die deelnemers gestyg vandat hulle die eerste monster gelewer het tot by die tweede monster later in die dag. Die deelnemers se speekselkortisolvlakke het nie noemenswaardig tussen die kontrole- en ingrypingsdae verskil nie.

Data van die vraelyste korreleer met die speekselkortisolvlakke van die deelnemers. Hoër angsvlakke het hoër speekselkortisolvlakke tot gevolg gehad. Lae tot matige angsvlakke, stres, depressie en hoe deelnemers die ingryping subjektief ervaar het, het geen ooreenkomskorrelasie met speekselkortisolvlakke gehad nie.

Om teksboodskappe te ontvang en die effek wat dit op menslike fisiologie het, is nie voldoende in die literatuur bestudeer nie. Hierdie studie is een van slegs ' $n$ handjievol studies om die effek wat die ontvang van boodskappe op speekselkortisolvlakke het, te bepaal. Sover vasgestel kon word, is dit die eerste studie om die effek, wat die ontvang van selfoonboodskappe op speekselkortisolvlakke het, in 'n lesingmilieu te bepaal.

Nota: 'n Seleksie van referatopsommings: Studentesimposium in die Natuurwetenskappe 31 Oktober - 1 November 2019 , Universiteit van die Vrystaat. Reëlingskomitee: Prof Rudi Pretorius (Departement Geografie, Universiteit van Suid-Afrika); Dr Hertzog Bisset (Suid-Afrikaanse Kernenergie-korporasie; Dr Ernie Langner (Departement Chemie, Universiteit van die Vrystaat) en Dr Wynand $\mathrm{Nel}$ (Departement Rekenaarwetenskap en Informatika, Universiteit van die Vrystaat). 